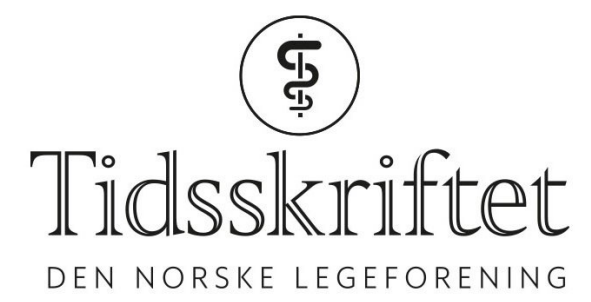

\title{
Norges helse er global helse, men får vi alle med?
}

\author{
DEBATT

\section{BERNADETTE KUMAR} \\ E-post: bernadette.kumar@nakmi.no \\ Bernadette Kumar er direktør ved Nasjonal kompetanseenhet for migrasjon og minoritetshelse \\ (NAKMI). \\ Forfatter har fylt ut ICMJE-skjemaet og oppgir ingen interessekonflikter.
}

Helsepolitikk er mer enn fastlege og sykehus. Fremtidens helseutfordringer fordrer politikere som tør utvide sine perspektiver både geografisk og sektorielt. Mitt ønske for valgkampen er politikere som lover å prioritere brede helsepolitiske virkemidler.

Jeg har lagt merke til at mange tenker på helsetjenester når de snakker om helsepolitikk. Dette er tjenester utført av helsepersonell, men utformet og styrt av politiske organer. For meg favner politikken langt videre. Helse formes av nesten alle politiske områder: utdanning, arbeid, ernæring, priser og avgifter og trafikkregler, for å nevne noen. I tillegg har nesten alle sider ved helsepolitikken de senere årene fått tydelige globale impulser.

I 2016 vedtok FN 17 bærekraftsmål for å bekjempe fattigdom og beskytte planeten, «Sustainable development goals» (SDGs). Ett av dem er direkte helserelatert, mens andre er knyttet til sult, utdanning, tilgang til rent vann, mulighet for anstendig arbeid, ulikheter og klima. Disse områdene er også førende for helsefeltet. Bærekraftsmålene er ikke bare helsepolitikk for fattige land, de angår oss alle. Men fortsatt er de et ukjent akronym for mange, også i helsepolitiske kretser.

For helsepolitikken globalt er universell dekning den nye utfordringen. Universell dekning handler om at alle skal være med. I ett av bærekraftsmålene heter det for eksempel: «leaving no one behind». Alle skal få tilgang til tjenester uten å bli påført en urimelig finansiell belastning. Universell helsedekning har tre dimensjoner. Den første gjelder hvor mye av kostnadene som skal dekkes, og den andre hvor stor del av befolkningen som skal dekkes. Den siste dimensjonen omhandler hvilke tjenester som skal dekkes.

Når det gjelder tjenestene, står vi oss godt i Norge. Men hva med samfunnsmedisin og helse på andre politiske områder? Nærmer vi oss universell, god helse? Ulikheter i helse har vært drøftet lenge, og med migrasjon har ulikhetene økt. I valgkampen ønsker politikerne å redusere ulikhetene. Men hva gjøres for å få alle med? Dersom vi er enige om at målet er bedre helse for alle, må vi tenke bredt når det gjelder virkemidlene.

\section{Bredt helsepolitisk begrep}

Verdens helseorganisasjon utformet i 2011 «25 x 25-initiativet». Målet var å redusere ikke- 
smittsomme sykdommer (betegnelsen er nokså håpløs medisinsk sett, men synes å fungere godt politisk) med 25\% innen 2025, herunder hjerte- og karsykdommer, lungesykdommer og kreft. Overvekt og diabetes regnes også med, men sees også som risikofaktorer sammen med alkohol, sedat livsstil, tobakk og høyt saltinntak. I den senere tid er også sosial rang kommet med som en tydelig risikofaktor for prematur $\mathrm{d} ø \mathrm{~d}$.

I fremtiden vil sykdomsbildet endre seg. Befolkningen blir eldre og mer mangfoldig, og folk har ofte mer enn én diagnose. Vi må ha det i bakhodet når vi skal bygge opp relevant kompetanse, fostre nye ferdigheter og revurdere funksjonene til helsepersonellet. Vi må dra nytte av klinisk kompetanse og ikke utelukkende satse på teknologiske løsninger.

I tillegg må helsepolitikken i større grad rette seg mot forebygging i bred forstand. Det betyr ikke bare å skue til tradisjonelle fysiske faktorer som forurensning, støy, trygg trafikk og anstendig og trygt arbeid, men å trekke sosiale determinanter som utdanning, økonomi og selvrespekt inn i helsepolitikken. Dette er faktorer som i høyeste grad er politisk påvirkelige. Forventet levetid har økt med nesten to måneder hvert år i vår levetid. Samtidig har de sosiale ulikhetene i levealder økt jevnt i Norge siden 196o-årene (1). Det er blitt sagt at helsetjenesten kan ta æren for om lag $20 \%$ av økningen i levealder. Resten ligger i faktorer utenfor.

Norge er en tydelig aktør i Genève og New York, også når det gjelder helsepolitikken. Slik jeg ser det, er grunnlaget for hva Norge mener i de store fora, blitt bedre de siste tiårene. Det er et fruktbart samarbeid mellom utenrikstjenesten og helsetjenesten her hjemme, men det kan bli bedre. Vi må arbeide for gjensidig utveksling av kunnskap og kompetanse mellom Norge og verdenssamfunnet. Et gledelig trekk kommer fra Det Norske Veritas, som har vakt oppsikt med sitt forsøk på å sertifisere «Spaceship Earth». Prosjektet går kort fortalt ut på å realitetsteste målene i FNs bærekraftsmål og retter seg spesifikt mot privat sektor og hva som må gjøres for å øke sjansene for å nå målene (2).

Jeg ønsker meg en stortingsperiode der hele Norges befolking er med, og hvor forskjeller reduseres. Man må tenke bredt på helsepolitikk, ikke bare i Helsedepartementet. Helsetjenesten må endres og utformes i takt med det endrede sykdomsbildet og befolkningssammensetningen. Slik jeg ser det, vil det innebære i større grad å bruke skatteog avgiftsvirkemidler for å oppnå helsegevinster, også på andre områder enn tobakk og alkohol. I tillegg må vi i større grad tar inn over oss de raske globale endringene og utviklingen i helse som direkte eller indirekte vil påvirke helsen i Norge.

LITTERATUR:

1. Folkehelseinstituttet. Levealderen i Norge.7.2.2017. https://www.fhi.no/nettpub/hin/befolkning-og-levealder/levealderen-i-norge-folkehelserap/ (3.8.2017).

2. DNV GL. The future of spaceship earth.

https://www.dnvgl.com/technology-innovation/spaceship-earth/index.html (3.8.2017).

Publisert: 4. september 2017. Tidsskr Nor Legeforen. DOI: 10.4045/tidsskr.17.0657

Mottatt 2.8.2017, godkjent 17.8.2017.

(C) Tidsskrift for Den norske legeforening 2020. Lastet ned fra tidsskriftet.no 